\title{
SCHOOL STAFF AND PARENTS' BELIEFS ABOUT THE ROLE OF SCHOOL FOR PUPILS' CHARACTER EDUCATION IN LATVIA
}

\author{
Svetlana Surikova, Manuel Joaquín Fernández González \\ University of Latvia Latvia
}

\begin{abstract}
This paper presents a mixed-method research aimed at identifying how school and teachers' role for character education at school is understood in Latvia. The theoretical framework of the study is based on the principles of virtue ethics. The viewpoints of 1116 respondents (parents, teachers, and school leaders) from all five regions of Latvia were collected in 2018-2020, using two questionnaires containing closed and open questions. The results provided new insights into how parents and school staff perceived the role of the school and the teachers in pupils' value and virtue education in Latvia. Schools should promote pupils' character development alongside academic excellence, but, while teachers should encourage good morals and values in pupils, using both 'caught' and taught' strategies, the main responsibility for children moral growth is on parents and families, not on teachers and the school. The majority of both school staff and parents were favourable to a shared responsibility and collaboration between school and family to promote character education inside and outside of the classroom.
\end{abstract}

Keywords: character education, character growth, school role, teacher's role, virtue ethics.

\section{Introduction}

In a virtue ethics perspective, which is the theoretical framework of this paper, character is defined as "a set of personal traits or dispositions that produce specific moral emotions, inform motivation and guide conduct [...]; character education includes all explicit and implicit educational activities that help young people develop positive personal strengths called virtues" (The Jubilee Centre for Character and Virtues, 2017, p. 2). Whilst parents are the primary educators of their children's character, "empirical research tells us that parents want all adults who have contact with their children to contribute to such education, especially their children's teachers" (The Jubilee Centre for Character and Virtues, 2017, p. 1). Besides parents, who should take the main role in their children's morality 
development, teachers also play an important role in promoting students' moral growth (Gui et al., 2020; Harrison et al., 2018), shaping the new generation and transmitting cultural and moral values to students (Gui et al., 2020, Velea \& Farca, 2013).

Character education at school can be implemented in different ways. The Character Education Evaluation Handbook for Schools (Harrison et al., 2015) conceptualises character education in terms of 'character caught' and 'character taught'. Caught approaches to character education emphasise the importance of teachers acting as positive role models for their students and the relevance of the school culture. Taught approaches are more explicit in developing students' character, for example, through discrete lessons focusing on character and virtues, or through embedding character education within subjects (Harrison et al., 2015, p. 11).

In Latvia, the Soviet heritage can still be felt in the way character education is implemented at school. During Communist character education, it was commonly accepted that "the ideology-driven political and moral upbringing at school [...] should be concentrated in the hands of the principal" (Klēgeris, 1962, p. 59). After the falling of Soviet Union, school leaders' formal authority increased, and the school role as a place for pupils' moral upbringing continued to be accepted in society (Fernandez Gonzalez, 2020). Among teachers, a tendency to consider themselves as experts who look with some mistrust at parental involvement in school settings can still be perceived, and the school role in moral education is somehow reinforced by a social context in which more than half of children live in broken families and where most parents are too busy earning money due to the low wages.

This historical and cultural background makes even more urgent the exploration of how the school and teachers' role in pupils' moral education is understood by the main actors of the education system in Latvia, which is the aim of this research.

To address the research goal, the following research questions were put forward:

1. How parents, teachers, and school leaders perceive the role of teachers and school in character education? This question was split in two sub-questions: a) Should character education be reserved to the family or is it also part of teachers' role? and b) Should the school limit itself to academic content or should it engage in character education?

2. Assuming that the provision of character education is part of the school and teachers' role, what approach should be adopted? This question was also split in two sub-questions: a) Should the school and the teachers limit their action to 'caught' approaches, or should they engage in 'taught' character education? and b) Should the 
school produce an official statement of the core character traits that it aims to develop in its pupils?

\section{Literature review}

The scientific literature regarding school and teachers' roles for character education and the types of school-family relationships is very abundant. For example, within the study conducted by the Commonwealth of Australia (2006), a school role typology was developed; the types are gathered under two big groupings such as 'Traditional roles' types (e. g., fully fledged partners, culture-changers, engagers, seekers, governance-oriented) and the 'Social change' types (e. g., social capital builders, resilience builders). In the first group were schools where the focus of the partnership was on the traditional educational functions of schools and in the second were schools where the focus of the partnership was on responding to wider imperatives deriving from community need (Commonwealth of Australia, 2006).

In addition, multiple theoretical models of school-family relationships (Auerbach, 2010; Bryan \& Henry, 2012; Cunningham \& Davis, 1985; Dale, 1996; Deslandes, 2019; Hornby, 2011; Lueder, 2000; Swap, 1993) have been defined, based on different sets of assumptions regarding the goals of, and strategies and approaches for, establishing a school-family relationship, and also the understanding of school and teachers' roles (see Table 1).

Scientific literature has also addressed the role of teachers in moral education. Pantić and Wubbels (2012) operationalized 'paternalist', 'liberal' and 'social-relativist' conceptions of teachers' moral roles among teachers from Bosnia \& Herzegovina and Serbia. And in a recent meta-analysis study based on published and unpublished studies in online data bases over 2009-2018 (Gui et al., 2020), seven roles of teachers in moral education were found: moral model, moral mentor, caregiver, moral value conveyer, facilitator, counsellor, and communicator.

Several associations around the world facilitate the school endeavour in the field of character education. In the UK, the Jubilee centre for Character and Virtues at the University of Birmingham, in its Character Education Evaluation Handbook for Schools, states that "Developing students' character is not new - it forms the time-honoured backbone of a school's and a teacher's role" (Harrison et al., 2015, p. 9). Under the section "Whole school community', the Handbook offers a set of criteria for assessing the role of teachers for character education according to four indicators ('Behaviours', 'Teaching virtues', 'Using virtues to develop independence' and 'Continuous professional development') and four levels for each indicator ('Focusing', 'Developing', 'Establishing', and 'Enhancing'), including descriptors of achievement for each level. 
Table 1. School and teachers' roles within theoretical models of school-family relationships

\begin{tabular}{|c|c|}
\hline $\begin{array}{l}\text { Models of school-family } \\
\text { relationships }\end{array}$ & $\begin{array}{l}\text { Role of the school and the teacher within } \\
\text { the model }\end{array}$ \\
\hline $\begin{array}{l}\text { The expert model (Cunningham \& } \\
\text { Davis, 1985). } \\
\text { The model preventing partnerships } \\
\text { (Auerbach, 2010). }\end{array}$ & $\begin{array}{l}\text { Teachers are experts who maintain control } \\
\text { over educational decisions. The school } \\
\text { and the teachers know what is better for } \\
\text { parents and their children. The school tells } \\
\text { parents what to do. }\end{array}$ \\
\hline The protective model (Swap, 1993). & $\begin{array}{l}\text { The teachers' role is to educate children at } \\
\text { school. }\end{array}$ \\
\hline $\begin{array}{l}\text { The transplant model (Cunningham } \\
\text { \& Davis, 1985). }\end{array}$ & $\begin{array}{l}\text { The teacher knows what parents ought to be } \\
\text { doing at home and what should be completed } \\
\text { at school. }\end{array}$ \\
\hline $\begin{array}{l}\text { The school-to-home transmission } \\
\text { model (Swap, 1993). }\end{array}$ & $\begin{array}{l}\text { The school should identify the values and } \\
\text { practices that contribute to success. }\end{array}$ \\
\hline $\begin{array}{l}\text { The consumer model (Cunningham } \\
\text { \& Davis, 1985). } \\
\text { The nominal partnership model } \\
\text { (Auerbach, 2010). }\end{array}$ & $\begin{array}{l}\text { The school is service-oriented. The teachers' } \\
\text { role is to provide their services to parents as } \\
\text { service consumers. }\end{array}$ \\
\hline $\begin{array}{l}\text { The curriculum enrichment model } \\
\text { (Swap, 1993). } \\
\text { The negotiating model (Dale, 1996). }\end{array}$ & $\begin{array}{l}\text { Teachers work together with parents to } \\
\text { enrich the curriculum and to take advantage } \\
\text { of parents' expertise. Both the teachers and } \\
\text { the parents make valuable contributions to } \\
\text { take the best decisions for children. }\end{array}$ \\
\hline $\begin{array}{l}\text { The traditional partnership model } \\
\text { (Auerbach, 2010). }\end{array}$ & $\begin{array}{l}\text { The school is more oriented on meeting } \\
\text { family needs, listening to parents and } \\
\text { bridging cultures as part of more responsive } \\
\text { leadership roles and a more family-friendly } \\
\text { school climate. }\end{array}$ \\
\hline $\begin{array}{l}\text { The partnership model } \\
\text { (Swap, 1993). }\end{array}$ & $\begin{array}{l}\text { Schools encourage an alliance between } \\
\text { parents and teachers. They work together to } \\
\text { accomplish the common mission of helping } \\
\text { all children in the school to achieve success. }\end{array}$ \\
\hline $\begin{array}{l}\text { The authentic partnership model } \\
\text { (Auerbach, 2010). }\end{array}$ & $\begin{array}{l}\text { The school is more oriented to ideals of } \\
\text { social justice, democracy, and cultural } \\
\text { responsiveness through more specific aims, } \\
\text { such as dialogue, parent advocacy, and } \\
\text { community revitalization. }\end{array}$ \\
\hline $\begin{array}{l}\text { The self-renewing partnership model } \\
\text { (Lueder, 2000). }\end{array}$ & $\begin{array}{l}\text { The school role is to support families, to } \\
\text { reach out and work with families using } \\
\text { connecting, communicating, coordinating, } \\
\text { and coaching strategies. }\end{array}$ \\
\hline
\end{tabular}


In the United States, the "11 Principles of Effective Character Education" (Character.org, 2018) proposed by the association Character.org, which are intended to support schools in establishing a comprehensive character development initiative, include explicit mentions to teachers' role for character education under the key indicators of exemplary implementation of the Principle 4 ('The school creates a caring community') and the Principle 8 ('All staff share the responsibility for developing, implementing, and modelling ethical character'), stating that "teachers understand that part of their role is to intentionally build relationships between all students in their classrooms" (Character.org, 2018, p. 17) and that "staff members will specifically cite their role as a model for student work and behaviour" (ibid., p. 29).

The themes regarding school-family partnerships and the teachers' and school role for character education were useful for the conceptualization of the research tools and for the interpretation of the results of this study.

\section{Method}

\section{Research tools, sampling, and data collection}

Two questionnaires were used for collecting data (see details further, in Table 3). The Questionnaire A was based on a poll (Populus, 2013) elaborated for the Jubilee Centre for Character and Virtues from the UK, which was translated into Latvian and validated in 2018. It contained four closed-ended questions for parents and school staff (school leaders and teachers): one about teachers' role (QA-1), two about the approaches to character education (QA-2 and QA-3) and one about the school role, which was common with the Questionnaire B (JQ-1). This second questionnaire was intended for school staff only and contained also two original open questions about school staff self-perceived role for character education: "What do you think is your role as a school staff representative in the moral development of pupils?" and "Do you think that your personal moral stance, your values and virtues, influence the moral development of pupils? Why? (If yes) In what way?"

The 'Questionnaire A' was administrated online and in paper in two steps: 1) from March to May 2018 - to 353 respondents from Riga within the Erasmus + project 'Arete Catalyst'; and from June till November 2018 - to 708 respondents from all Latvian regions within the first stage of the postdoctoral research 'Arete-school' (Fernández González, 2019). All respondents participated voluntarily. The 'Questionnaire B' was administrated in paper form in February-March 2020 to 55 in-service teachers $(n=23)$ and school leading staff $(n=32)$ from Riga and Riga surroundings who participate voluntarily in the second stage of the 'Arete-school' 
postdoctoral study - a professional development course about character and virtue education (Fernández González, 2020).

This research used a sample of 1116 respondents: 461 parents, 496 in-service teachers and 159 school leading staff (see Table 2). Respondents were between 23 and 78 years old $(M=45.37, S D=9.74)$, and $91.7 \%$ were females. The overall work experience of school leaders and teachers oscillated between 1 and 54 years $(M=22.07, S D=12.25)$. All five planning regions of Latvia were represented in the research as follows: $37.5 \%$ from Riga city and Riga region, 13.5\% from Latgale, $11.0 \%$ from Kurzeme, 12.1\% from Vidzeme and $25.9 \%$ from Zemgale.

Table 2. Respondent groups

\begin{tabular}{|l|l|l|l|l|}
\hline $\begin{array}{l}\text { Respondent } \\
\text { group }\end{array}$ & $\begin{array}{l}\text { Within Arete } \\
\text { Catalyst } \\
\text { Study 1 in } \\
\text { Riga city }\end{array}$ & $\begin{array}{l}\text { Within } \\
\text { Arete-school } \\
\text { Study 1 in } \\
\text { five planning } \\
\text { regions }\end{array}$ & $\begin{array}{l}\text { Within Arete- } \\
\text { school Study } \\
\text { 2 in Riga } \\
\text { region }\end{array}$ & Total \\
\hline Parents & 190 & 271 & 0 & 461 \\
\hline Teachers & 110 & 363 & 23 & 496 \\
\hline School leaders & 53 & 74 & 32 & 159 \\
\hline Total & $\mathbf{3 5 3}$ & $\mathbf{7 0 8}$ & $\mathbf{5 5}$ & $\mathbf{1 1 1 6}$ \\
\hline
\end{tabular}

\section{Organization of the data and data analysis methods}

The data obtained were first organized according to the research questions. The data referring to the $1^{\text {st }}$ research question were obtained from questions QA-1 and JQ-1, and those referring to the $2^{\text {nd }}$ research question from questions QA-2 and QA-3 (see Table 3). Processing and analysis of quantitative data were performed using IBM SPSS Statistics 26 software. Crosstabulation was used to display a breakdown of the quantitative data, to create contingency tables, which describe the interaction between two nominal variables (in our study - three respondent groups and their beliefs regarding teachers' and school role in character education). Via Crosstabs, Chi-square test of independence was performed to determine if there was a significant relationship between two nominal variables, Z-test was employed to compare column proportions and Bonferroni method was used to adjust the significance values. The answers to the open questions (Questionnaire B) were analysed using traditional content analysis (thematic coding and grouping categories), and they used for illustrating the quantitative findings. 


\section{Results}

Research results are presented by research questions. The first one ('How parents, teachers, and school leaders perceive the role of teachers and school in character education?') included two sub-questions:

RQ1-a: Should character education be reserved to the family or is it also part of teachers' role?

According to crosstab statistics (see Table 3, question QA-1), overall, $65.8 \%$ of respondents $(N=687)$ agreed that it is part of a teacher's role to encourage good morals and values in pupils, $25.8 \%$ of respondents disagree, and $8.4 \%$ did not have a clear opinion.

Table 3. School and teacher's role to encourage good morals and values in pupils

\begin{tabular}{|c|c|c|c|c|c|}
\hline \multirow{3}{*}{$\begin{array}{l}\text { Question / } \\
\text { statement }\end{array}$} & \multirow[t]{3}{*}{ Answer } & \multicolumn{3}{|c|}{ Respondent group } & \multirow[t]{2}{*}{ Total } \\
\hline & & Parents & Teachers & \begin{tabular}{|l} 
School \\
leaders
\end{tabular} & \\
\hline & & $\%(n)$ & $\%(n)$ & $\%(n)$ & $\%(N)$ \\
\hline \multirow{3}{*}{$\begin{array}{l}\text { QA-1: Do you } \\
\text { think it is part of } \\
\text { a teacher's role to } \\
\text { encourage good } \\
\text { morals and values } \\
\text { in pupils? }\end{array}$} & $\begin{array}{l}\text { Yes, it is a } \\
\text { teacher's role }\end{array}$ & $54.9(253)_{\mathrm{b}}$ & $73.1(339)_{a}$ & $74.8(95)_{a}$ & $65.8(687)$ \\
\hline & $\begin{array}{l}\text { No, it is not } \\
\text { a teacher's } \\
\text { role }\end{array}$ & $34.9(161)_{b}$ & $16.8(78)_{a}$ & $23.6(30)_{a}$ & 25.8 (269) \\
\hline & Don't know & $8.5(39)_{a}$ & $10.1(47)_{\mathrm{a}}$ & $1.6(2)_{b}$ & $8.4(88)$ \\
\hline \multirow{2}{*}{$\begin{array}{l}\text { JQ-1: Schools } \\
\text { should develop } \\
\text { pupils' character } \\
\text { and encourage } \\
\text { good values in } \\
\text { them. }\end{array}$} & Agree & $66.2(300)_{a}$ & $80.5(392)_{b}$ & $88.4(137)_{b}$ & $75.3(829)$ \\
\hline & Disagree & $33.8(153)_{a}$ & $19.5(95)_{b}$ & $11.6(18)_{b}$ & 24.7 (266) \\
\hline \multirow[b]{2}{*}{$\begin{array}{l}\text { QA-2: It is possible } \\
\text { to teach a child } \\
\text { values and shape } \\
\text { pupil's character } \\
\text { in a positive way } \\
\text { at school, through } \\
\text { lessons, team- } \\
\text { building exercises } \\
\text { or voluntary work }\end{array}$} & Agree & $92.3(418)_{a}$ & $91.6(426)_{\mathrm{a}}$ & $89.0(113)_{\mathrm{a}}$ & $91.6(957)$ \\
\hline & Disagree & $7.7(35)_{a}$ & $8.4(39)_{a}$ & $11.0(14)_{\mathrm{a}}$ & $8.4(88)$ \\
\hline \multirow{3}{*}{$\begin{array}{l}\text { QA-3: Do you think } \\
\text { that schools should } \\
\text { have a statement of } \\
\text { the core character } \\
\text { traits that it aims } \\
\text { to develop in its } \\
\text { pupils? }\end{array}$} & $\begin{array}{l}\text { Yes, they } \\
\text { should }\end{array}$ & $31.8(144)_{\mathrm{a}, \mathrm{b}}$ & $26.9(125)_{a}$ & $38.6(49)_{b}$ & $30.4(318)$ \\
\hline & $\begin{array}{l}\text { No, they } \\
\text { shouldn't }\end{array}$ & $43.3(196)_{a}$ & $47.5(221)_{a}$ & $48.0(61)_{a}$ & $45.8(478)$ \\
\hline & Don't know & $24.9(113)_{b}$ & $25.6(119)_{b}$ & $13.4(17)_{\mathrm{b}}$ & 23.8 (249) \\
\hline
\end{tabular}


Even if positive answers were more frequent in all groups, there were some differences among them: Parents less likely than teachers and school leaders ascribed this role to teachers; and school leaders were group who answered more positively and with less hesitation. A Chi-square test of independence was performed to examine the statistical significance of the relation between each respondent group and its beliefs regarding the teacher's role. The relation between these variables was significant: $X^{2}(4, N=1044)=52.252, p=.000$.

Note: Z-test \& Bonferroni method were employed via Crosstabs to compare column proportions and to adjust p-values. Each subscript letter denotes a subset of respondent group categories (i. e., parents, teachers and school leaders) whose column proportions do not differ significantly from each other at the .05 level.

The open answers to the Questionnaire B illustrate these quantitative findings. Some teachers stressed that moral education is part of a teacher's role, but it is not the teacher's responsibility. As a school leader put it: I believe it is really part of the role of teacher, but it is not just the responsibility of the teacher. The education of each child is, firstly, the responsibility of the family, secondly, the responsibility of society. Every adult who meets a child is a model of virtue and character (School leader 1).

Regarding the way school leaders and teachers perceived their role in pupils' moral growth (51 utterances), 39.2\% of respondents believe that they have an extremely important role. In $56.9 \%$ of the utterances (29 times) they perceived themselves as role models for pupils, colleagues and parents, as illustrated by these respondents' comments: Both colleagues and pupils look at the school staff as a role model, and then they accept or do not accept what we say about values and behaviour (School leader 2); I consider myself as a role model for colleagues, pupils an parents (School leader 3); I may give both a positive and a negative example, and others learn from what they see (Teacher 1). In addition, 17 utterances referred directly to their role of supporting, inspiring, and motivating pupils: Pupils spend most of their day at school, and the teacher is precisely the person who can support, encourage, and teach them (Teacher 2); and four utterances from school leaders referred to their leadership role at school level (giving official support to moral education, organising the curriculum and school events, creating a school atmosphere supportive of character education, etc.

Analysing school leaders' and teachers' answers to the question "Do you think that your personal moral stance, your values and virtues, influence the moral development of pupils? Why? (If yes) In what way?" 49 utterances were found: 34 utterances (69.4\%) referred to the impact they can have through the example of their own virtues, in particular being coherent, as illustrated by these respondents' comments: I am aware that my 
behaviour impacts pupils who see it; this is why I deliberately use this influence at work, trying to do my best for demonstrating a high moral behaviour (School leader 4); I try to be a honest and authentic person, I think this helps students (Teacher 3). And 15 utterances (30.6\%) addressed the importance of mutual relationships: speaking with pupils, being open with them about one's feelings and values, giving them time and attention, adapting to their needs, and providing opportunities for mutual collaboration. As respondents put it: I try not to impose my moral views and values, but I give pupils the opportunity to know how I think and to decide by themselves what they want to take from it (Teacher 4); I am always attentive to pupils' reactions and moods... and I try to help them. I also always tell them about my feelings and emotions... (School leader 5).

RQ1-b: Should the school limit itself to academic content or should it engage in character education?

Overall, most respondents $(75.7 \%, N=829)$ agreed that schools should seek to develop pupils' character (see Table 3, question JQ-1), but there were remarkable differences among groups: While the overwhelming majority of school leaders and teachers agreed $(88.4 \%$ and $80.5 \%$ respectively), only $66.2 \%$ of parents did so. These differences among groups were statistically significant $\left(X^{2}(2, N=1095)=41.761, p=.000\right)$.

In their open answers, one of the teachers commented, I believe that teachers are already devoting a lot of their time to educating pupils morally ... and I do not know any teacher who would teach children the opposite or who is indifferent to non-virtuous, unethical behaviour (Teacher 5). A school leader also commented that Academic education is not valuable when pupils have no understanding of virtues and lack of a strong character (School leader 6). A parent abounded in this sense: In primary education schools, the development of social skills (collaborative skills, communication skills, self-assertiveness skills and listening to others, tolerance and dignity, civic participation, skills to seek and verify information, etc.) is the key. The development of these skills now seems to be left to the parents alone. But children spend a lot of time at their educational institution (sometimes even more than with their family). It is therefore essential that the school is involved in raising children character (Parent 1).

On the other side, one of the parents explained in the following way her concern about the school engaging too much in children's moral education: I don't think it's the responsibility of the school. I don't expect it from school. Raising my children's character is primarily my responsibility as a parent. Only then comes role of the school, the teachers; and I assume they do it when appropriate. Thanks to them for that! (Parent 2).

The second research question ('Assuming that providing character education is part of the school and teachers' role, what approach should be adopted?') was also split in two sub-questions: 
RQ2-a: Should the school and the teachers limit their action to 'caught' approaches, or should they engage in 'taught' character education?

The overwhelming majority of respondents $(91.6 \%, N=957)$ agreed that it is possible to teach values through lessons and other character 'taught' activities (see Table 3, question QA-2), and there were not statistically significant differences among respondent groups $\left(X^{2}(2, N=1045)=1.400\right.$, $p=.497)$. In their open answers, parents gave some examples about how this can happen: Children with parents need to fill out a growth journal, including personality growth (Parent 3); There is a code of class behaviour, green/red badges about behaviour in a given week are given, kids learn to work on a team, to respond adequately to losses, particularly in sport, we talk about mutual relationships (Parent 4). Other parents mentioned the contexts in which this 'taught' moral education happens: The class teacher regularly addresses these topics in form time. She pays attention to moral values; she talks about and explains them to pupils (Parent 5); During form time, and in ethics and social science lessons, many topics that are relevant to children, family and society are examined and discussed (Parent 6); In history, literature, and philosophy lessons, there are lively conversations about the human condition and about actions based directly on character traits (Parent 7).

RQ2-b: Should the school produce an official statement of the core character traits that it aims to develop in its pupils?

As shown in Table 3 (Question QA-3), overall, 45.8\% of respondents $(N=478)$ disagreed and only $30.4 \%$ agreed to that question, but almost $1 / 4$ of respondents did not have a clear position about it $(23.8 \%)$. In all groups the negative answer was more frequent. School leaders were much less hesitant in their opinion than the other groups (only 13.4\% of them did not know how to answer, while the figure was $24.9 \%$ for teachers and even higher $-25.6 \%$ for parents). The majority of school leaders was against officially stating core character traits, but they were also the group who had the highest percent of positive answers to this question, while parents were the group that has the lowest percent of negative answers (43.3\%). The relation between each respondent group and its opinion about the school statement of the core character traits was also statistically significant, $X^{2}(4, N=1045)=12.704, p=.013$. In their open comments, some parents emphasized that the school has its own value document, and you can also find a description of the values in the interior of the school (Parent 8), and that values are defined at school; the school has done value-defining work together with parents and is currently introducing them in different ways at school (Parent 9). 


\section{Discussion}

This study showed that, in Latvia, a number of parents and school staff believe that (1) schools should seek to develop pupils' character and encourage good values in them alongside academic study, but it is not necessary that the school has an official statement of values and core character traits; (2) it is part of teachers' role to encourage good morals and values in pupils, but the main responsibility for this task should be put on parents and families, not on teachers and the school; and (3) it is possible to use 'taught' approaches to character education at school.

These results, found in Latvian context, could be compared with similar international research. A polling carried out by Populus (2013) for the Jubilee Centre for Character and Values found an even stronger support among parents in the UK for the promotion of character development alongside academic study at school: In the UK, 87\% of parents felt that schools should focus both on character development and academic study, not simply on academic study alone, while in Latvia the figure was $66.2 \%$ for parents (and $84.4 \%$ of school staff). In the UK, $84 \%$ of parents believed that it is a teacher's role to encourage good morals and values in pupils, while in Latvia the figure was $54.9 \%$ of parents (and $73.9 \%$ of school staff). Regarding the possibility of adopting 'taught approaches' for transmitting values to children and shaping their character in a positive sense, the situation in UK and in Latvia is quite similar: 95\% of parents in Populus study and $92.3 \%$ of Latvian parents (and $90.3 \%$ of school staff) agreed to it. The biggest difference between the two countries was in the opinion about the convenience of having an official core statement of values and core character traits that schools instilled/aimed to develop in their pupils: while in the UK $81 \%$ of parents agreed, in Latvia only $31.8 \%$ of parents (and $32.7 \%$ of school staff) were favourable to it.

The majority of school staff and parents participating in this study supported the idea of shared responsibility and collaboration between school, family, and society to promote character education. This finding is in line with the understanding of effective partnerships reported by scientific literature: effective partnerships are based on mutual trust, respect, and shared responsibility for children's learning and development (Auerbach, 2010; Barr \& Saltmarsh, 2014; Bryan \& Henry, 2012; Epstein et al., 2002; Lueder, 2000; The Family-School and Community Partnerships Bureau, 2008). This finding should be taken into account when considering how to elaborate effective school-family collaboration models to deliver character education because both "parents and teachers are the educators of their children's character, inside and outside of the classroom" (Harrison et al., 2018, p. 3). Other international research has also found that, in character education, 
which is "not a slogan or a course but a mission that is embedded in the everyday school life" (Agboola \& Tsai, 2012, p. 168), it is necessary to create effective school-family partnerships to encourage students to acquire good virtues and manifest good values in their lives (Agboola \& Tsai, 2012; Berkowitz \& Bier, 2006; Berkowitz et al., 2008, 2017; Epstein et al., 2002).

Recent approaches to character education had stressed that pupils' virtue growth can be achieved not only through the observation of role models (caught approaches) and character instruction (taught approaches), but also through pupils' autonomous reflection and reasoning (sought approaches) (Harrison et al., 2018, p. 7), which can be facilitated by personal engagement and individual conversations. Therefore, the main roles of teachers and parents in character education could be listed as follows: role models, instructors, mentors, and facilitators of pupils' reflection. School-family or teacher-parent partnership for character education should aim at activating and promoting a mechanism of self-directed character growth in each pupil to provide gradually a shift from school-family shared responsibility to a situation where the pupils themselves are personally aware and responsible for improving their own character, their moral stance and their behaviour, and for building their own value and virtue system; one that is internally accepted by and personally significant for them.

\section{Acknowledgements}

This work was supported by the EU European Regional Development Fund under postdoctoral research grant No 1.1.1.2/VIAA/1/16/071 and by the University of Latvia under Grant No ZD2010/AZ22, research project "Human, technologies and quality of education".

\section{References}

Auerbach, S. (2010). Beyond coffee with the principal: Toward leadership for authentic school-family partnerships. Journal of School Leadership, 20(6), 728-757.

Barr, J., \& Saltmarsh, S. (2014). 'It all comes down to the leadership': The role of the school principal in fostering parent-school engagement. Educational Management Administration \& Leadership, 42(4), 491-505.

Berkowitz, M. W., \& Bier, M. C. (2006). What works in character education: A researchdriven guide for educators. Character Education Partnership.

Berkowitz, M. W., Battistich V. A., \& Bier M. C. (2008). What works in character education: What is known and what needs to be known. In L. P. Nucci \& D. Narvaez (Eds.), Handbook of moral and character education (pp. 414-431). Routledge.

Berkowitz, M. W., Bier, M. C., \& McCauley, B. (2017). Toward a science of character education: Frameworks for identifying and implementing effective practices. Journal of Character Education, 13(1), 33-51. 
Bryan, J., \& Henry, L. (2012). A model for building school-family-community partnerships: Principles and process. Journal of Counseling \& Development, 90(4), 408-420.

Character.org. (2018). 11 principles of effective character education: A guide to cultivating a culture of character. Character.org.

Commonwealth of Australia. (2006). Family-school partnerships project: A qualitative and quantitative study. http://familyschool.org.au/files/6613/7955/4781/muller.pdf

Cunningham, C., \& Davis, H. (1985). Working with parents: Frameworks for collaboration. Open University Press.

Dale, N. (1996). Working with families of children with special needs: Partnership and practice. Routledge.

Deslandes, R. (2019). A framework for school-family collaboration integrating some relevant factors and processes. Aula Abierta, 48(1), 11-18.

Epstein, J. L., Sanders, M. G., Simon, B. S., Salinas, K. C., Rodriguez Jansorn, N., \& Van Voorhis, F. L. (2002). School, family, and community partnerships: Your handbook for action ( $2^{\text {nd }}$ ed.). Corwin Press, Sage Publications Company.

Fernández González, M. J. (2019). Skolēnu morālā audzināšana Latvijas skolās: vecāku, skolotāju, topošo skolotāju un skolu un izglitïbas pārvalžu vaditāju viedokli [Moral education of pupils in Latvian schools: The views of parents, teachers, future teachers, heads of schools and education boards]. LU PPMF Pedagoǵijas zinātniskais institūts. Retrieved from: http:// dspace.lu.lv/dspace/bitstream/handle/7/46498/Zi\%20ojums_Skol\%20nu\%20mor\% 201\%20\%20audzin\%20\%20ana\%20Latvijas\%20skol\%20s.pdf?sequence $=1$

Fernández González, M. J. (2020). Assessment of a pilot programme for supporting principals' leadership for character education in Latvian schools. Master thesis submitted in partial requirement of MA in Character Education. Jubilee Centre for character and virtues, University of Birmingham. Retrieved from: https://dspace.lu.lv/dspace/handle/7/52875

Gui, A. K. W., Yasin, M., Abdullah, N. S. M., \& Saharuddin, N. (2020). Roles of teacher and challenges in developing students' morality. Universal Journal of Educational Research, 8(3C), 52-59. https://doi.org/10.13189/ujer.2020.081606

Harrison, T., Arthur, J., \& Burn, E. (2015). Character education evaluation handbook for schools. University of Birmingham, Jubilee Centre for Character and Virtues. Retrieved from: https://www.jubileecentre.ac.uk/1721/character-education/teacher-resources/ evaluation-handbook-for-schools

Harrison, T., Dineen, K., \& Moller, F. (2018). Parent-teacher partnerships: Barriers and enablers to collaborative character education. University of Birmingham, Jubilee Centre for Character and Virtues. Retrieved from: http://jubileecentre.ac.uk/userfiles/ jubileecentre/pdf/projects/TransformativeBritain/ParentTeacher_Partnerships.pdf

Hornby, G. (2011). Parental involvement in childhood education: Building effective schoolfamily partnerships. Springer.

Klēǵeris, N. (1962). Padomju skolas tradīiju iedzìvināšana un saglabāšana [Soviet traditions in our schools: How to instil and retain them]. Audzināšanas jautājumi padomju skolā, 48(1), 55-80.

Lueder, D. C. (2000). Creating partnerships with parents: An educator's guide. Scarecrow Press.

Pantić, N., \& Wubbels, T. (2012). The role of teachers in inculcating moral values: operationalisation of concepts. Journal of Beliefs \& Values, 33(1), 55-69. https://doi.org/ $10.1080 / 13617672.2012 .650030$ 
Populus. (2013). A framework for character education: Jubilee Centre parents' survey. Retrieved from: https://www.jubileecentre.ac.uk/userfiles/jubileecentre/pdf/charactereducation/Populus\%20Parents\%20Study\%20-\%20short.pdf

Swap, S. M. (1993). Developing home-school partnerships: From concepts to practice. Teachers College Press, Columbia University.

The Family-School and Community Partnerships Bureau. (2008). Family-school partnerships framework: A guide for schools and families. Australian Government, Department of Education, Employment and Workplace Relations. Retrieved from: https://issr.uq.edu. au/files/3754/Family-school\%20partnerships\%20framework.pdf

The Jubilee Centre for Character and Virtues. (2017). A framework for character education in schools. University of Birmingham, Jubilee Centre for Character and Virtues. Retrieved from: http://jubileecentre.ac.uk/userfiles/jubileecentre/pdf/character-education/Framework\%20for\%20Character\%20Education.pdf

Velea, S., \& Farca, S. (2013). Teacher's responsibility in moral and affective education of children. Procedia - Social and Behavioral Sciences, 76, 863-867. https://doi.org/ 10.1016/j.sbspro.2013.04.221 